\title{
Prolonged use of the food dye tartrazine (FD\&C yellow n⿳5) and its effects on the gastric mucosa of Wistar rats
}

\author{
Moutinho, ILD. ${ }^{\mathrm{a} *}$, Bertges, LC. ${ }^{\mathrm{b}}$ and Assis, $R V C$. $^{\mathrm{c}}$ \\ aBiology, Post-graduation Program, Universidade Federal de Juiz de Fora - UFJF, \\ Campus Universitário, CEP 36036-330 Martelos, Juiz de Fora - MG, Brazil \\ ${ }^{b}$ Department of Physiology, Institute of Biology, UFJF \\ 'Department of Pathology, School of Medicine, UFJF \\ *e-mail: ivanadamasio@terra.com.br
}

Received April 29, 2005 - Accepted August 24, 2005 - Distributed Februay 28, 2007

(With 3 figures)

\begin{abstract}
Tartrazine is one of the most widely used artificial foods, drugs and cosmetic dyes. It is a nitrous derivative and is known to cause allergic reactions such as asthma and urticaria, as well as having been the focus of studies on mutagenesis and carcinogenesis due to its transformation into aromatic amine sulfanilic acid after being metabolized by the gastrointestinal microflora. 45 male Wistar rats were assigned to a control group (A) or a treatment one (B). The treatment group received $7.5 \mathrm{mg} \cdot \mathrm{kg}^{-1}$. day ${ }^{-1}$ of tartrazine daily in drinking water offered ad libitum for ten months from weaning to the age of twelve months. There was a significant increase in the number of lymphocytes and eosinophils of the gastric antrum mucosa. No carcinogenetic changes in any gastric area were observed during the study. As tartrazine belongs to the azo class, it is still a possible food carcinogen. Other studies with different doses and schedules, observing their effects associated to other carcinogens should be carried out if their safe use is to be recommended.
\end{abstract}

Keywords: tartrazine, food dye, gastric mucosa, rats.

\section{Uso prolongado do corante alimentar tartrazina (FD\&C yellow $\mathbf{N}^{0} 5$ ) e seus efeitos em mucosa gástrica de ratos Wistar}

\begin{abstract}
Resumo
O corante artificial tartrazina é um dos mais usados em todo o mundo para corar alimentos, medicamentos e cosméticos. É um derivado nitroso, sabidamente causador de reações alérgicas como asma e urticária, e tem sido alvo de estudos de mutagênese e carcinogênese por produzir a amina aromática ácido sulfanílico após ser metabolizado pela microflora gastrintestinal. Foram estudados 45 ratos Wistar, machos, divididos em grupo controle (A) e tratado (B). O grupo tratado recebeu o corante diariamente em água de beber ad libitum, na dose de 7,5 mg.kg- ${ }^{-1} \cdot \mathrm{di}^{-1}$ por dez meses, do desmame aos doze meses de idade. Houve aumento significante do número de linfócitos e eosinófilos na mucosa do antro gástrico. Não foram observadas alterações carcinogênicas em nenhuma das regiões gástricas com a dose e o tempo utilizados. O corante tartrazina permanece entre os possíveis carcinógenos alimentares por ser da classe azo, devendo ter prosseguimento seus estudos; variando-se a dose e o tempo de administração e verificando-se seus efeitos quando associado a outros carcinógenos, para seu uso continuar sendo recomendado com segurança.
\end{abstract}

Palavras-chave: tartrazina, corante alimentar, mucosa gástrica, ratos.

\section{Introduction}

A wide range of food additives, running into more than 2,500 items used to preserve, dye or enhance foods (Toledo, 1996, 1999; Hirschbruch and Torres, 1998) are a consequence of industrialization and the development of food processing technology. A food additive is only approved for human consumption after studying its acute, sub-acute and chronic toxicity. Nevertheless, postmarketing surveillance of its effects must be kept for a long time. Information concerning the safety of long term use of such chemicals, their combined effect and mutability within the organism is scarce. The individual response varies not only according to dose, age, gender, nutritional status and genetic factors, but also according to long term exposure to low doses (Sandler, 1983; Volpi, 1985; Hurtado, 1998; Sasaki et al., 2002).

Several metabolites of these substances, such as nitrous compounds, have been found to be carcinogens. Toxicity or benefit depend on to what extent food com- 
ponents affect absorption, excretion or the metabolism as a whole. Because there may be interaction among different substances, the definition of adequate safety limits for human consumption is further compounded (Preussmann, 1978; Fergunson, 1999).

An improper diet is known to account for one third of all malignancies (Conference Review, 1999) and while some additives are essential for the preservation of food, others only have a cosmetic role (Hurtado, 1998).

The Codex Alimentarius (FAO/WHO) issued by the Expert Committee on Food Additives - JECFA) recommends the acceptable daily intake (ADI) based on the non observed adverse effect level (NOAEL), expressed as $\mathrm{mg} . \mathrm{kg}^{-1}$ of body weight. The ADI for tartrazine is $7.5 \mathrm{mg} / \mathrm{kg} /$ day (Toledo, 1996; Hirschbruch and Torres, 1998; Walton et al., 1999).

Tartrazine is an azobenzene artificial yellow dye whose structure features a trisodium salt of 3-carboxy5-hydroxy-1 (p-sulfophenyl) -4- (sulfophenyl azo) pirazolone. It is widely used to dye sweets, chewing gum, jellies, puddings, juices, jams, mustard, sodas, drugs and cosmetics. Because it is a nitrous derivative (azo class) it is reduced in the organism to an aromatic amine which is highly sensitizing. Its main metabolite identified to date is sulfanylic acid (Jones et al., 1964; Roxon et al., 1967; Chung et al., 1992; Maekawa et al., 1987).

Tartrazine has been implicated as the food additive most often responsible for allergic reactions, having thus been targeted by the scientific community. Although urticaria, asthma, purpura and eczema have been described, chiefly affecting individuals allergy to aspirin, the underlying immunologic mechanism has proved elusive. Some studies have suggested a humoral immune response brought about by the sulfanyl group (Geller, 1987; Marisol and Modesto, 1989; Devlin and David, 1992; Corder and Buckley, 1995). Some countries such as Sweden, Switzerland and Norway have withdrawn tartrazine on the grouds of its anaphylactic potential (Wüthrich, 1993).

The Brazilian Sanitary Surveillance Agency (ANVISA), based on the severe, albeit rare, side effects of tartrazine demanded a label warning for tartrazinedyed drugs with effect as of 2002: This product contains the yellow dye tartrazine (FD\&C Yellow $N^{\circ} 5$ ), which may cause allergic reactions such as bronchial asthma and urticaria in susceptible people (Anvisa, 2002).

Some authors have studied the carcinogenetic and mutagenetic effects of tartrazine with variable results (Jones et al., 1964; Roxon et al., 1967; Patterson and Butler, 1982; Maekawa et al., 1987; Borzelleca and Hallagan, 1988; Collins et al., 1990, 1992; Reyes et al., 1996; Koutsogeorgopoulou et al., 1998; Walton et al., 1999; Sasaki et al., 2002;). In this study we have investigated inflammatory, atrophic, atypical, metaplastic, dysplastic and carcinogenetic changes in the gastric mucosa of rats receiving tartrazine daily in their drinking water, for a prolonged period of time.

\section{Material and Method}

\subsection{Animals}

45 albino male 26-day-old Wistar rats (Rattus norvegicus) obtained from the Center for Reproduction Biology of the Universidade Federal de Juiz de Fora were used. After spending one week in groups of nine animals for adaptation, the rats were kept in individual cages. The study lasted 46 weeks (10 months), a period corresponding approximately to one third of the animals` lifespan.

There were two groups: A (controls), with 22 rats, receiving daily mineral water and food ad libitum; $\mathrm{B}$ (treatment), with 23 animals also receiving daily tartrazine-added mineral water $\left(7.5 \mathrm{mg} \cdot \mathrm{kg}^{-1} \cdot \mathrm{dia}^{-1}\right)$ and food $\mathrm{ad}$ libitum. The daily volume of water offered was calculated as a means of daily intake referred to in the literature for the species (23), followed by daily observation and measurement of the volume actually taken by each animal. The next dose was adjusted to avoid any left-over and guarantee dye intake. The animals were weighed and the cages cleaned once a week to minimize stress.

In the $46^{\text {th }}$ week, the animals were killed by ether inhalation and necropsied, removing the oesophagusgastro-duodenal segment, subsequently opened through the greater curvature. All specimens were examined for gross changes and then fixed in $10 \%$ formaline for 24 hours. 3 fragments from each animal yielded 4 regions to be studied: squamous gastric fundus, glandular fundus, body and antrum.

The specimens were (Prophet et al., 1994 ) processed according to standardized procedures for a histological study (24). For each fragment, a randomly limited horizontal $1 \mathrm{~cm} \times 0.2 \mathrm{~mm} \times 0.1 \mathrm{~mm}$ section corresponding to the gastric wall thickness was obtained. The fragments were divided into 25 high-power fields ( $\mathrm{HPF}-400 \mathrm{X}$ ).

For each of the four regions, the number of mitoses, the presence of atypia and atrophy, the number of eosinophils and lymphocytes, and the number of argentaffin granular cells were observed.

\subsubsection{Qualitative analysis}

This was used to decide the presence of atrophy and the nature (nodular or diffuse) of the lymphocytic infiltrate.

\subsubsection{Semi-quantitative analysis}

The presence of atypia, lymphocytes and argentaffin granular cells were estimated by using a $1+$ to $3+$ scores: $1+=$ mild; $2+=$ moderate; $3+=$ severe. Mild atypia was defined as regular outline cariomegaly, slightly enlarged and evident nucleolus and smooth chromatin. Moderate atypia was composed of the same criteria for mild one plus irregular nuclear outline. The addition of dense chromatin, enlargement of the nucleolus and loss of nuclear polarity in the moderate stage made up severe atypia.

The number of lymphocytes was considered small (1+) when they occupied up to $35 \%$ (one third) of the fragment. It was considered moderate $(2+)$ when lymphocytes occupied up to $70 \%$ (two thirds) of the fragment. 
Lymphocytes occupying more than $70 \%$ (two thirds) of the fragment were considered a large number $(3+)$.

Argentaffin granular cells were a small number (1+) if there were up to 5 cells per field. Moderate $(2+)$ and large $(3+)$ numbers were considered when there were 6 to 9 and 10 or more cells, respectively.

\subsubsection{Quantitative analysis}

To analyze the eosinophilic and mitotic cellular component, the grated eyepiece technique was used.

\subsubsection{Statistical analysis}

The data were studied according to Mann-Whitney`s non- parametric test ( $\mathrm{p}<0.05$ ) (Triola, 1999 and Vieira, 1986).

\section{Results}

Only two animals did not survive till the end of the study. Moreover, no other pathologic events were observed during the 46 weeks of the study.

Animal number 6, from group A, died in the $39^{\text {th }}$ week and no cause was determined by necropsy. Animal number 30 , from group $\mathrm{B}$, died in the $40^{\text {th }}$ week due to indifferentiated round cell malignancy involving the intestinal wall and pancreas, with liver metastases.

\subsection{Results of qualitative analysis}

\subsubsection{Atrophy}

No animal showed an atrophyc pattern of gastric mucosa in any of the sites studied.

\subsubsection{Pattern of lymphocytic infiltrate}

This was predominantly diffused with $50 \%$ of the animals in group B showing an association of diffuse and nodular patterns in the antrum $(\mathrm{p}<0.05)$.

\subsection{Results of the Semi-quantitative Analysis}

\subsubsection{Atypia}

This was mild (1+) in group A, with 3 animals showing no atypia whatsoever.

In group B mild atypia (1+) also predominated with 3 animals showing foci of moderate and severe atypia $(\mathrm{p}>0.05)$.

\subsubsection{Lymphocytes}

Small numbers (1+) were predominant, except for the antral mucosa of animals in the treatment group, where $45 \%$ of the animals showed $2+$ infiltrates and one animal showed a $3+$ infiltrate $(\mathrm{p}<0.01)$ (Figure 1).

\subsubsection{Argentaffin granular cells}

These cells were observed in all animals in both groups, always in small numbers by ( $p>0.05)$.

\subsection{Results of the quantitative analysis}

\subsubsection{Eosinophils}

They were predominant in the antrum of animals from the treatment group $(\mathrm{p}<0.05)$ (Figure 2).

\subsubsection{Mitoses}

There was greater mitotic activity in the squamous epithelium of the gastric fundus and no significant difference between the 2 groups were found by $(p>0.05)$. (Figure 3).

\section{Discussion}

Our results have shown that daily yellow dye tartrazine, at the acceptable daily intake dose, significantly increased the number of eosinophils in the antrum and also produced an even more significant increase of lymphocytes in the same region.

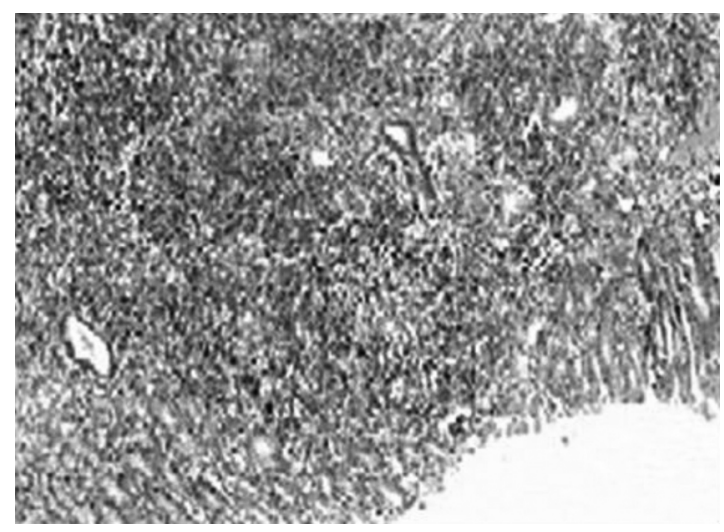

Figura 1. Knotty backlog of lymphocytes.



Figura 2. Fragment of antrum with predominance of eosinophils and mitoses

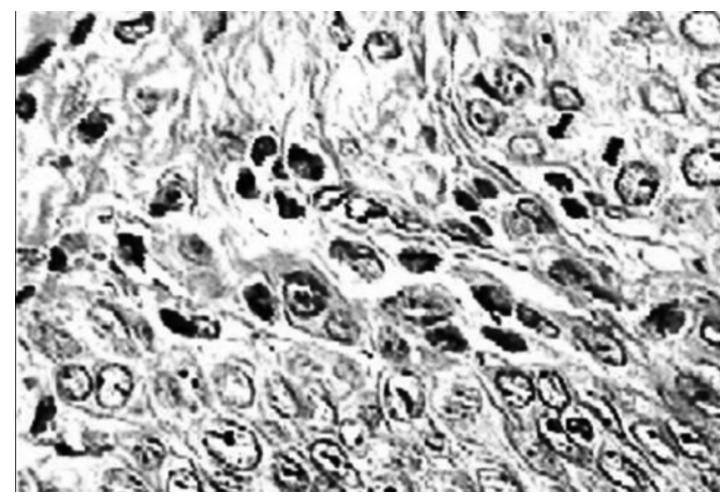

Figura 3. Mitoses. 
We have not been able to find studies specifically targeting changes in the gastric mucosa of rats on tartrazine, although Aboel-Zahab et al. (1997) describe an increase in blood eosinophils of albino rats receiving an association of tartrazine-containing dyes for 30 and 60 days. These authors also found pigment in the portal vein tract, Van Küpffer cells and renal interstitial and tubular cells.

Sasaki et al. (2002) in a study relating tartrazine use to gastrointestinal cells showed DNA damage in rats receiving tartrazine as $10 \mathrm{mg} \cdot \mathrm{kg}^{-1}$ or $100 \mathrm{mg} \cdot \mathrm{kg}^{-1}$ single doses. The increase in the number of gastric lymphocytes we were able to show has not been previously described, although an experimental study with a different method describes cytotoxicity and immunosuppressive effects of tartrazine on human peripheral blood lymphocytes, with mitotic proliferation and inhibition of their lytic activity (Koutsogeorgopoulou et al., 1998).

Ishidate et al. (1984) describe the appearance of chromosomic aberrations in fibroblasts of tartrazinetreated Chinese guinea pigs. In a study with fibroblasts from the Muntiacus muntijac mammal, cultivated in vitro with 5,10 , and $20 \mu \mathrm{g}$ of tratrazine for 3 days, fibroblastic chromosome aberrations were also found (Patterson and Butler, 1982).

Inhibition of mitochondrial respiration of $16 \%$ of liver and kidney cells from tartrazine-treated rats was demonstrated in a study by Reyes et al. (1996).

We found neither carcinogenetic lesions in the gastric cells nor a significant presence of other malignancies in the animals, in accordance with the data from Borzelleca and Hallagan (1988) who failed to show any significant difference in the incidence of neoplastic lesions in animals receiving tartrazine orally in 4 different concentrations for 2 years. Notwithstanding, these authors highlighted the production of the aromatic amine sulfanylic acid by the intestinal microflora of animals on tartrazine.

The increased number of cells from the immune system found in this study underscores the known allergenic effect of tartrazine and may constitute another carcinogenetic hazard, adding to the uncertainty surrounding its use, due to the association with the production of sulfanylic acid.

The teratogenetic effect of tartrazine was tested by Collins et al. $(1990,1992)$ in female rats receiving the drug through gavage or orally on days 0 and 19 of pregnancy and no significant differences were found between treated animals and controls.

Histopathological analysis of the stomachs of animals in groups A and B showed the presence of argetanffin granular cells, responsible for gastrointestinal mesenchimal tumors in humans. Statistical analysis did not show any relation between the number of such cells and the gastric changes found. We could not find any literature reference to these cells in tartrazine-treated rats (Rubin et al., 2000).

We acknowledge that diluting the dye in water and offering it ad libitum was not the best way to guarantee a precise intake, although several authors have offered tartrazine ad libitum in water or food (Maekawa et al., 1987; Borzelleca and Hallagan, 1988; Collins, 1992; Aboel-Zahab, 1997). The long period of the study coupled with insurmountable technical difficulties precluded the daily gavage of the animals. We believe our approach was worthy in terms of intake, which was close to the maximum intended.

The diversity of results found in studies on tartrazine, coupled with its ability to sensitize and produce aromatic amine, clearly point to the need for further studies to determine its carcinogenetic potential, cytotoxicity, and immunosuppressive effects. So that the continued use of tartrazine in foods and drugs can be justified, studies using different doses and schedules, and investigating its combined effect with other food and environmental carcinogens are called for.

Acknowledgments - I am indebted to the following medical undergraduates (UFJF) for their invaluable help with animal care: Carolina Frade Magalhães Pimentel, Priscilla Ornellas Neves and Cristiano de Paula Souza.

\section{References}

ABOEL-ZAHAB, H., EL-KHYAT, Z. and SIDHOM, G., 1997. Physiological effects of some synthetic food colouring additives on rats. Boll. Chim. Farm., vol. 136, no. 10, p. 615-27.

ANVISA, AGÊNCIA NACIONAL DE VIGILÂNCIA SANITÁRIA., 2002. Resolução n. 572, 5 de abril de 2002. Diário Oficial da União, 66. Brasília, DF, 8 abril 2002. Seção 1.

BORZELLECA, JF. and HALLAGAN JB., 1988. Chronic toxicity/carcinogenicity studies of FD \& C yellow $\mathrm{n}^{\circ} 5$ (tartrazine) in rats. Food. Chem. Toxicol., vol. 26, no. 3, p. 179-87.

CHUNG, KT., STEVENS JR., E., CERNIGLIA, CE., 1992. The reduction of dyes by the intestinal microflora. Crit. Rev. Microbiol., vol. 18, no. 3, p. 175-190.

COLLINS, TFX., BLACK, TN., BROWN, LH. and BULHACK, P., 1990. Study of the teratogenic potencial of FD \& C Yellow $\mathrm{n}^{\circ} 5$ when given by gavage to rats. Food Chem. Toxic., vol. 28, no. 12 , p. $821-827$.

COLLINS, TFX., BLACK, TN., BULHACK, P. and O'DONNELL, MW., 1992. Study of the teratogenic potencial of FD \& C Yellow $n^{\circ} 5$ when given in drinking-water. Food Chem. Toxic., vol. 30, no. 4, p. 263-268.

CONFERENCE REVIEW., 1999. Food, Nutrition and the Prevention of Cancer: A Global Perspective. Nutrition, vol. 15, no. 6, p. 523-526.

CORDER, HE. and BUCKLEY, E. III., 1995. Aspirin, Salicylate and Tartrazine Induced Bronchonstriction. Safe doses and Case Definition in Epidemiological Studies. J. Clin Epidemiol, vol. 48 , no. 10 , p. $1269-1275$.

DEVLIN, J. and DAVID, TJ., 1992. Tartrazine in atopic eczema. Arch Des Child, vol. 67, p. 709-711.

FERGUNSON, LR., 1999. Natural and man-made mutagens and carcinogens in the human diet. Mut. Res., vol. 433, no. 1-2, p. 1-10. 
GELLER, M., 1987. Aditivos: Alergia e Idiossincrasia. J. bras. Med., vol. 53, no. 2, p. 56-60.

HIRSCHBRUCH, MD. and TORRES, EAFS., 1998. Toxicologia de Alimentos: Uma Discussão. Hig. Alim., vol. 12, no. 53 , p. 21-25.

HURTADO, RM., 1998. Reacciones adversas a alimentos y sus aditivos. Pediatr Dia., vol. 14, no. 3, p. 128-31.

ISHIDATE, M., SOFUNI, JR., T. and HAYASHI, M.,1984. Primary mutagenicity screening of food additives currently used in Japan. Food Chem. Toxicol. 22, 623 apud MAEKAWA et al. 1987. LacK of Carcinogenecity of Tartrazine (FD \& C YELLOW N ${ }^{\circ}$ ) in the F344 Rat. Food Chem. Toxicol., vol. 25, no. 12 , p. 891-96.

JONES, R., RYAN, AJ. and WRIGHT, SE., 1964. The metabolism and excretion of tartrazine. Food Cosmet Toxicol., vol. $2,447 \mathrm{p}$

KOUTSOGEORGOPOULOU, L., MARAVELLAS, C. and METHENITOU, G., 1998. Immunological Aspects of the Common Food colorants, Amaranth and Tartrazine. Vet. Hum. Toxicol., vol. 40, no. 1, p. 1-4.

MAEKAWA, A., MATSUOKA, C., ONODERA, H., TANIGAWA, H., FURUTA, K., KANNO, J. and JANG, JJ., 1987. LacK of Carcinogenecity of Tartrazine (FD \& C YELLOW N ${ }^{\circ}$ 5) in the F344 Rat. Food Chem. Toxicol., vol. 25, no. 12 , p. 891-896.

MARISOL, LMG. and MODESTO, OS., 1989. Estudio de la frecuencia de urticaria y angiodema inducidos por aditivos de alimentos. Alerg. Imunol. Clin., vol. XXXVI, no. 1. Enerofebrero.

PATTERSON, RM. and BUTLER, JS., 1982. Tartrazine induced chromosomal aberrations in mammalian cells. Food Chem. Toxicol., vol. 20, no. 4, p. 461-5.

PREUSSMANN, R., 1978. Toxicological aspects of food safety- Carcinogenicity and mutagenicity. Arch. Toxicol. Suppl, vol. 1, p. 69-84.
PROPHET, EB., MILLIS, B., ARRINGTON, JB. and SOBIN, LH., 1994. Laboratory Methods in Histotechnology, Washington DC: Amer. Reg. Pathol. 55p.

REYES, FGR., VALIM, FC. and VERCESI, AE., 1996. Effect of organic synthetic food colours on mitocondrial respiration. Food Addit Contam., vol. 13, no. 1, p. 5-11.

ROXON J., RYAN, A. and WRIGHT, S., 1967b. Enzymatic reduction of tartrazine by Proteus vulgaris from rats. Food Cosmet Toxicol., vol. 5, p. 645.

RUBIN BP., FLETCHER JA. and FLETCHER CDM., 2000. Molecular insights into the histogenesis and pathogenesis os gastrintestinal stromal tumors. Int. J. Surg Pathol, vol 8, no. 1, p. $5-10$.

SANDLER, RS., 1983. Diet and Cancer: Food Additives, Coffee and Alcohol. Nutr. Cancer, vol. 4, no. 4, p. 273-9.

SASAKI, YUF., KAWAGUCHI, S., KAMAYA, A., OHSHITA, M., KABASAWA, K., IWAMA, K., TANIGUCHI, K. and TSUDA, S., 2002. The comet assay with 8 mouse organs: results with 39 currently used food additives. Mutat. Res., vol. 519, p. 103-119.

TOLEDO, MCF.. 1996. Aditivos Alimentares in Fundamentos de Toxicología. Atheneu. Brasil. p. 405-39.

TOLEDO, MCF., 1999. Regulamentação de Uso de Corantes Naturais. Arch. Latinoam Nutr., vol. 49, no. Supl 1, p. 67-70.

TRIOLA, MF., 1999. In Introdução à Estatística. Rio de Janeiro. LTC, 360p.

VIEIRA, S., 1986. In Introdução a Estatística. Ed. Campus, 292p.

VOLPI, EL., 1985. Aditivos Alimentares. Aliment. Nutr., vol 6, no. 23 , p. $40-44$.

WALTON, K., WALKER, R., VAN DE SANDT, JJM., and CASTELL, JV., 1999. The Application of In Vitro in the Derivation of the Acceptable Daily Intake of Food Additives. Food Chem Toxicol., vol. 37, p. 1175-1197.

WÜTHRICH, B., 1993. Adverse reactions to food additives. Ann. Allergy., vol. 71, no. 4, p. 379-84. 